\title{
Studi Penelitian Tindakan Kelas: Bagaimana Meningkatkan Pemahaman Matematis pada Siswa?
}

\author{
Rani Sugiarni $^{1 *}$, Ari Septian ${ }^{1}$, Dadang Juandi ${ }^{2}$, Siti Julaeha ${ }^{1}$ \\ ${ }^{1}$ Pendidikan Matematika, Universitas Suryakancana, Indonesia \\ ${ }^{2}$ Pendidikan Matematika, Universitas Pendidikan Indonesia, Indonesia \\ *rani@unsur.ac.id
}

\begin{tabular}{|c|c|}
\hline Article Info & Abstract \\
\hline $\begin{array}{l}\text { Received } \\
03 \text { March } 2021\end{array}$ & $\begin{array}{l}\text { Learning models that are not precise have an impact on low student } \\
\text { understanding so that the student completeness score is still below } \\
50 \% \text {, so appropriate action is needed to improve the quality of learning } \\
\text { so that students' understanding in learning mathematics increases. The }\end{array}$ \\
\hline $\begin{array}{l}\text { Revised } \\
14 \text { April } 2021\end{array}$ & $\begin{array}{l}\text { purpose of this study was to determine the increase in mathematical } \\
\text { understanding of students by using cooperative learning model type } \\
\text { Snawbal throwing. This type of research is classroom action research }\end{array}$ \\
\hline $\begin{array}{l}\text { Accepted } \\
01 \text { May } 2021\end{array}$ & $\begin{array}{l}\text { through } 3 \text { cycles. The increase in learning outcomes is determined } \\
\text { based on an increase in the average understanding of students, the } \\
\text { attainment of absorption and learning completeness. Increment refers }\end{array}$ \\
\hline Keywords & $\begin{array}{l}\text { to the ratio between the value of cycle I, cycle II and cycle III. The } \\
\text { results showed that the implementation of the snowball throwing type } \\
\text { of cooperative learning model could improve students' mathematical }\end{array}$ \\
\hline Action research & understanding of set matterial. It can be seen from the students' \\
\hline $\begin{array}{l}\text { Mathematical } \\
\text { understanding }\end{array}$ & $\begin{array}{l}\text { average understanding of mathematics increased from } 75 \text { (cycle I) to } 9 \\
\text { (cycle II), and } 82 \text { (cycle III). The increase also occurred in the }\end{array}$ \\
\hline Cooperative & $\begin{array}{l}\text { attainment of absorption and learning completeness. The absorption } \\
\text { capacity increased from 50\% to } 70 \% \text { and } 73 \% \text {. The learning } \\
\text { completeness has increased from } 50 \% \text { to } 70 \% \text { and } 73 \% \text {. }\end{array}$ \\
\hline & pyright $\odot 2020 \mathrm{JIM}$, all rights reserved. Authors agree that this article remains permanently open access \\
\hline
\end{tabular}

How to Cite:

Sugiarni, R., Septian, A., Juandi, D., \& Julaeha, S. (2021). Studi Penelitian Tindakan

Kelas: Bagaimana Meningkatkan Pemahaman Matematis Pada Siswa?. Journal of Instructional Mathematics, 2(1), 21-35.

\section{PENDAHULUAN}

Pendidikan sangat penting bagi manusia karena merupakan wadah untuk mendapatkan berbagai macam pengetahuan, keterampilan, dan perubahan sikap serta tingkah laku. Di dalam pendidikan, terdapat proses belajar. Proses inilah yang menghasilkan perubahan-perubahan tersebut. Ini sesuai dengan pernyataan Gross \& Thompson (2007) menyatakan bahwa "Pendidikan adalah pengaruh lingkungan atas individu untuk menghasilkan perubahan-perubahan yang menetap di dalam kebiasaan-kebiasaan, pemikiran, sikap-sikap, dan tingkah laku".

Pendidikan merupakan upaya untuk meningkatkan kualitas setiap individu, secara langsung disiapkan untuk menopang dan mengikuti laju perkembangan ilmu pengetahuan dan teknologi dalam upaya meningkatkan mutu pendidikan yang sejalan dengan proses belajar mengajar. Keberhasilan pendidikan akan dicapai suatu bangsa apabila ada usaha untuk meningkatkan mutu pendidikan bangsa itu sendiri. Pendidikan adalah usaha sadar untuk menumbuhkembangkan potensi sumber daya manusia. Fungsi dan tujuan pendidikan nasional menurut 
Pasal 3 Undang-Undang Nomor 20 Tahun 2003 tentang Sistem Pendidikan Nasional menyatakan bahwa "Pendidikan nasional berfungsi mengembangkan kemampuan dan membentuk watak serta peradaban bangsa yang bermartabat dalam rangka mencerdaskan kehidupan bangsa. Bertujuan untuk berkembangnya potensi untuk peserta didik agar menjadi manusia yang beriman dan bertaqwa kepada Tuhan Yang Maha Esa, berakhlak mulia, sehat, berilmu, cakap, kreatif, mandiri, dan menjadi warga negara yang demokratis serta bertanggung jawab".

Upaya untuk meningkatkan mutu pendidikan itu sudah banyak dilakukan oleh pemerintah, diantaranya pembaharuan kurikulum, perbaikan sarana dan prasarana pendidikan, penggunaan metode mengajar, melaksanakan penelitian serta meningkatkan kualitas dan kuantitas bahan ajar. Namun, seberapa upaya yang dilakukan pemerintah hingga saat ini masih banyak mendapat kritikan dari media massa yang mengatakan bahwa mutu pendidikan di Indonesia masih tergolong rendah.

Guru merupakan faktor penentu terhadap berhasilnya proses pembelajaran di samping faktor pendukung yang lainnya. Guru sebagai fasilitator dalam mentransfer ilmu pengetahuan kepada siswa. Di dalam kegiatannya guru mempunyai metode-metode yang paling sesuai untuk suatu bidang studi. Sehubungan dengan fungsinya sebagai pengajar, pendidik, dan pembimbing, maka diperlukan adanya berbagai peranan pada diri guru yang senantiasa menggambarkan pola tingkah laku yang diharapkan dalam berbagai interaksinya. Penerapan metode mengajar yang tepat diperlukan demi berhasilnya proses pendidikan dan usaha pembelajaran di sekolah.

Matematika merupakan ilmu universal yang mendasari perkembangan teknologi modern, mempunyai peran penting dalam berbagai disiplin ilmu pengetahuan dan mengembangkan daya pikir manusia. Untuk menguasai dan menciptakan teknologi di masa depan, diperlukan penguasaan matematika yang kuat sejak dini. Ruseffendi (1991: 260) menyatakan bahwa "matematika timbul karena pikiran-pikiran yang berhubungan dengan ide, proses dan penalaran".

Berdasarkan Undang-Undang Republik Indonesia Nomor 20 Tahun 2003 tentang Sistem Pendidikan Nasional Pasal 37 ayat (1) disebutkan bahwa Kurikulum pendidikan dasar dan menengah wajib memuat: Pendidikan Agama; Pendidikan Kewarganegaraan; Bahasa; Matematika; Ilmu Pengetahuan Alam; Ilmu Pengetahuan Sosial; Seni dan Budaya; Pendidikan Jasamani dan Olahraga; Keterampilan/Kejujuran; dan Muatan Lokal (DEPDIKNAS, 2005).

Dalam undang-undang di Republik Indonesia Nomor 20 Tahun 2003 tentang Sistem Pendidikan Nasional Pasal 37 ayat (1), tampak jelas bahwa matematika adalah salah satu mata pelajaran yang wajib diajarkan di sekolah-sekolah terutama Sekolah Menengah Pertama (SMP). Pendidikan matematika diharapkan mampu mengembangkan nilai, sikap serta keterampilan siswa untuk dapat menelaah kehidupan dimasyarakat yang dihadapi sehari-hari.

Matematika juga merupakan salah satu mata pelajaran yang dipelajari secara bertahap dan berkelanjutan. Sebagaimana telah dinyatakan oleh Suherman dkk (2003), bahwa "konsep-konsep Matematika tersusun secara hierarkis, terstruktur, logis, dan sistematis mulai dari konsep yang paling sederhana sampai pada konsep yang paling kompleks". Oleh karena kehierarkian matematika tersebut, maka dalam belajar matematika harus dilakukan secara bertahap, berurutan disesuaikan dengan tingkat perkembangan berpikir siswa dan berkelanjutan berdasarkan pada 
pengalaman yang lalu. Siswa tingkat SMP akan mempelajari konsep matematika berdasarkan pemahaman konsep matematika yang diperoleh dibangku Sekolah Dasar (SD), begitu pula siswa tingkat Sekolah Menengah Atas (SMA) akan mempelajari konsep matematika berdasarkan konsep yang diperoleh di SMP.

Kegiatan belajar mengajar tidak terlepas dari metode pembelajaran. Pemilihan model atau metode pembelajaran sangat menentukan keberhasilan belajar dalam hal ini keberhasilan belajar siswa. Metode yang digunakan tidak sembarangan, melainkan sesuai dengan tujuan pembelajaran (Rusmana \& Isnaningrum, 2015).

Salah satu kenyataan yang sering hadir pada pembelajaran matematika adalah bahwa pembelajaran matematika yang dilaksanakan dewasa ini lebih cenderung pada pencapaian target materi atau sesuai isi materi buku yang digunakan sebagai buku wajib dengan berorientasi pada soal-soal ujian nasional. Akibatnya kecerdasan yang dimiliki oleh siswa tidak tergali dengan baik.

Berkenaan dengan hal di atas, Ruseffendi (1991) menyatakan bahwa, terdapat banyak anak yang setelah belajar matematika bagian yang sederhana banyak yang tidak dipahaminya, bahkan banyak konsep yang dipahami secara keliru, matematika dianggap sebagai ilmu yang sukar, ruwet dan banyak memperdayakan.

Sebagian anak yang mengalami kesulitan belajar matematika disebabkan mereka bukan memahami konsepnya melainkan hanya menghafal saja, sehingga dalam menerapkan suatu konsep matematika, mereka tidak dapat menerapkannya dalam kehidupan sehari-hari.

Selain konsep belajar yang keliru, pandangan siswa terhadap matematika sebagai ilmu yang sukar dan ruwet juga karena dipengaruhi oleh motivasi belajar mereka yang rendah. Ketika siswa merasa tidak dapat mengerjakan soal matematika, maka mereka akan berhenti sampai disitu tanpa mau lagi berusaha mengerjakannya. Apalagi jika guru matematika diam tidak memperhatikan siswa tersebut, maka akan terjadi rasa malas dan tidak berminat untuk belajar matematika. Walaupun matematika merupakan pelajaran yang berdaya guna tinggi, namun sebagian besar siswa masih kurang termotivasi dalam belajar matematika. Mereka masih beranggapan bahwa matematika merupakan pelajaran yang sulit, sukar, dan menegangkan. Hal ini didukung dengan sebagian besar guru matematika yang berpenampilan kurang familiar atau terlalu serius, selain itu kurang adanya teknik motivasi yang diberikan kepada siswa yang berkemampuan kurang terhadap matematika. Oleh karena itu, motivasi belajar siswa menjadi kurang optimal dan sebagai akibat adalah hasil belajarnya yang rendah.

Hasil belajar matematika siswa dipengaruhi oleh faktor internal dan faktor eksternal. Faktor internal merupakan faktor yang berasal dari dalam diri siswa itu sendiri, seperti motivasi, kecerdasan logika matematis, kecerdasan emosional, rasa percaya diri, kemandirian, sikap dan lainnya. Sedangkan faktor eksternal merupakan faktor yang berasal dari luar diri siswa, seperti sarana dan prasarana, lingkungan, kurikulum, metode mengajar, dan motivasi dari guru itu sendiri.

Dari kedua faktor tersebut, ternyata saling mendukung satu sama lain. Metode mengajar dan guru menjadi faktor eksternal yang juga berpengaruh di dalam kelas. Jika metode yang digunakan hanya mencatat, kemudian memberikan tugas tanpa diperiksa hasil pekerjaan siswa, maka hasil belajar akan rendah. Begitu pula jika terdapat siswa yang kurang dalam pelajaran matematika, kemudian guru 
tersebut diam tanpa memberikan motivasi kepada siswa tersebut, maka hasil belajar dan motivasi belajar siswa tersebut akan rendah.

Selain itu, faktor intenal yakni motivasi juga biasanya berasal dari dalam diri siswa itu sendiri dengan belajar di rumah dan belajar di sekolah yang dipandu oleh guru. Jika hasil belajar siswa rendah, maka guru dapat memberikan siswa tersebut berupa hadiah agar mereka lebih semangat untuk belajar dan mencapai hasil yang diinginkan. Dengan demikian, metode pembelajaran yang menarik dan teknik motivasi yang dilakukan guru akan berpengaruh terhadap hasil belajar matematika siswa.

Keberhasilan proses belajar dan mengajar dipengaruhi oleh beberapa faktor, diantaranya pemilihan metode atau model pembelajaran, minat siswa terhadap materi yang diajarkan dan peranan guru dalam mengatasi kesulitan belajar siswa serta motivasi dari siswa itu sendiri untuk belajar dan memahami materi.

Banyak ditemui siswa seringkali takut apabila diminta untuk mengerjakan soal ke depan kelas, karena takut salah dan ditertawakan oleh teman-teman sejawatnya. Terkadang siswa kurang paham dengan penyampaian dan malas untuk bertanya, padahal sebenarnya siswa memiliki kemampuan yang kurang baik. Kurangnya pengetahuan siswa, sehingga menyebabkan siswa kesulitan untuk memulai mengerjakan soal yang diberikan oleh guru karena kurang paham terhadap rumus-rumus. Ketidaktepatan teknik pembelajaran yang diterapkan oleh pengajar, sehingga menyebabkan proses pembelajaran terkesan monoton.

Berdasarkan dari hasil nilai siswa kelas VII C SMPN 1 Kadupandak dirasa kurang paham terhadap materi yang sudah diberikan oleh guru, ini dilihat dari nilai ketuntasan siswa yang masih di bawah KKM, rata-rata nilai ketuntasan sebesar $43 \%$ jelas ini menjadi suatu permasalahan serius di mana sebagian besar siswa nilainya kurang dari KKM. Salah satu faktor adalah pengaruh lingkungan sekolah yang kurang mendukung seperti keadaan di dalam kelas yang kurang kondusif. Akibatnya, siswa kurang serius untuk belajar matematika, sehingga mempengaruhi hasil belajar siswa. Ini yang mendasari penelitian ini dilakukan di SMPN 1 Kadupandak, yaitu karena siswanya yang kurang tertarik dengan pembelajaran matematika sehingga mempengaruhi hasil belajarnya. Peneliti berharap agar penelitian ini bisa bermaanfaat dan bisa merubah persepsi siswa tentang mata pelajaran matematika yang menyulitkan menjadi mudah dan menyenangkan dengan model pembelajaran snowball throwing.

Snowball throwing adalah salah satu model pembelajaran kooperatif. Menurut Abdurrahman \& Bintoro (2000) bahwa "pembelajaran kooperatif adalah pembelajaran yang secara sadar dan sistematis mengembangkan interaksi yang silih asah, silih asih, dan silih asuh antar sesama siswa sebagai latihan hidup di dalam masyarakat nyata". Model pembelajaran ini dapat digunakan untuk memberikan konsep pemahaman materi yang sulit kepada siswa. Metode snowball throwing juga untuk mengetahui sejauh mana pengetahuan dan kemampuan siswa dalam menguasai materi tersebut.

Pada model pembelajaran snowball throwing siswa dibentuk menjadi beberapa kelompok. Dipilih ketua kelompok yang akan mewakili untuk menerima tugas dari guru. Masing-masing siswa membuat pertanyaan yang dibentuk seperti bola (kertas pertanyaan) lalu dilempar ke siswa lain kemudian siswa menjawab pertanyaan dari bola yang didapatkan. Snowball throwing melatih siswa untuk lebih tanggap menerima pesan dari orang lain, dan menyampaikan pesan tersebut 
kepada temannya dalam satu kelompok. Lemparan pertanyaan menggunakan kertas berisi pertanyaan yang diremas menjadi sebuah bola kertas kemudian dilemparkan kepada siswa lain. Siswa yang menerima bola kertas lalu membuka dan menjawab pertanyaannya (Suprijono, 2010).

Diharapkan dengan model pembelajaran Snowball Throwing, maka pemahaman matematis siswa dapat meningkat. Dalam National Council of Teachers of Mathematics (NCTM, 1989), dipaparkan bahwa pemahaman matematis merupakan aspek yang sangat penting dalam prinsip pembelajaran matematika. Pemahaman matematis lebih bermakna jika dibangun sendiri oleh siswa. Oleh karena itu, kemampuan pemahaman tidak dapat diberikan dengan pemaksaan.

Menurut Sumarmo (2010), pemahaman matematis adalah pemahaman yang meliputi: (1) pemahaman induktif, meliputi: pemahaman dalam melaksanakan perhitungan rutin, algoritma, dan menerapkan rumus pada suatu kasus matematis, (2) pemahaman intuitif, meliputi: pemahaman dalam membuktikan kebenaran suatu teorema dan mengaitkansatu konsep dengan konsep lainnya. Menurut Skemp (dalam Nurdiawan, Maryam, Lutfia, Trisatria, Hermawan \& Hidayat, 2019), Pemahaman matematis didefinisikan sebagai kemampuan yang mengaitkan notasi dan simbol matematika yang relevan dengan ide-ide matematika dan mengkombinasikannya ke dalam rangkaian penalaran logis. Siswa perlu dibekali dengan kemampuan pemahaman matematis agar siswa tidak mengalami kesulitan dalam memahami dan menyelesaikan permasalahan dalam matematika (Syafrianto, Kusumah \& Juandi, 2016)

Adapun indikator kemampuan pemahaman konsep matematika adalah: (1) menyatakan ulang secara verbal konsep yang telah dipelajari; (2) mengklasifikasikan objek-objek berdasarkan dipenuhi atau tidaknya persyaratan untuk membentuk konsep tersebut; (3) menerapkan konsep secara algoritma; (4) menyajikan konsep dalam berbagai macam bentuk representasi matematika; dan (5) mengaitkan berbagai konsep (Fajriah \& Sari, 2016; Hutagalung, 2017; Mawaddah \& Maryanti, 2016; Ningrum, Purnami, \& Widodo, 2017; Widodo, Ayuningtyas \& Sumarti, 2019; Septian \& Ramadhanty, 2020).

Berdasarkan catatan-catatan yang dikemukakan, maka perlu adanya tindakan yang tepat yang harus dipersiapkan dalam meningkatkan kemampuan pemahaman matematis siswa. Oleh karena itu, studi ini ditujukan untuk menjawab pertanyaan bagaimana meningkatkan pemahaman matematis pada siswa?

\section{METODE PENELITIAN}

Jenis penelitian ini adalah penelitian tindakan kelas (classroom action reseach). Penelitian tindakan kelas (PTK) adalah suatu penelitian yang dilakukan oleh guru atau seseorang tertentu di dalam kelas dengan tujuan untuk memperbaiki kinerja sebagai guru, sehingga hasil belajar siswa menjadi meningkat. Tahapan penelitian terdiri 3 siklus, setiap siklus terdiri atas empat langkah, yaitu: (1) perencanaan, (2) aksi atau tindakan, (3) observasi, dan (4) refleksi.

Penelitian ini dilaksanakan di SMPN 1 Kadupandak. Subjek dari penelitian ini adalah siswa kelas VII yang berjumlah 28 orang. Adapun faktor-faktor yang diteliti dalam penelitian ini adalah: (1) faktor siswa yang terdiri dari peningkatan pemahaman matematis siswa pada materi segiempat melalui penerapan model 
pembelajaran snowball throwing; dan (2) faktor guru yaitu aktivitas guru selama pembelajaran melalui penerapan model pembelajaran snowball throwing.

Prosedur penelitian yang digunakan dalam penelitian ini, yaitu prosedur penelitian tindakan kelas yang dilaksanakan dalam tiga siklus. Masing-masing siklus mengikuti tahapan (1) perencanaan, (2) aksi atau tindakan, (3) observasi, dan (4) refleksi. Materi siklus I meliputi himpunan, materi siklus II meliputi menentukan himpunan bagian dan menentukan banyak himpunan bagian, sedangkan materi siklus III meliputi operasi irisan, gabungan, kurang (difference), dan komplemen pada himpunan.

Instrumen yang digunakan dalam penelitian ini antara lain tes setiap siklus, lembar observasi setiap siklus, dan jurnal. Adapun teknik dalam pengumpulan data dengan data kuantitatif dengan menanalisis nilai setiap siklus pada nilai ratarata, daya serap klasikal (DSK) dan ketuntasan belajar, sedangkan data kualitatif dengan menganalisis lembar observasi dan jurnal.

\section{HASIL DAN PEMBAHASAN}

Pada Penelitian Tindakan Kelas dimulai dengan observasi yang berupa pemberitahuan sekaligus permintaan izin kepada kepala sekolah dan orientasi lapangan yang bertujuan untuk mengetahui dan menemukan masalah yang berhubungan dengan proses pembelajaran matematika, setelah mengetahui masalahnya maka mencari solusi dengan membuat perencanaan tindakan pembelajaran untuk melakukan perbaikan dalam upaya meningkatkan pemahaman matematis siswa pada pembelajaran matematika.

Hasil wawancara dengan guru mata pelajaran matematika pembelajaran masih secara klasikal yaitu dengan metode ekspositori. Selama pembelajaran tampak beberapa siswa saja yang aktif mengemukakan pendapatnya, yang lainnya hanya menerima apa yang dikonfirmasikanoleh guru tanpa betul-betul memahami konsep yang sedang diajarkan, sehingga saat diadakan latihan berupa soal uraian masih banyak siswa yang belum bisa mengerjakan soal tersebut.

Pelaksanaan Pembelajaran siklus I, Tindakan pembelajaran yang dilakukan pada siklus I disesuaikan dengan RPP. Kegiatan pembelajaran pada pokok bahasan Himpunan yaitu tentang mengetahui notasi pembentuk himpunan dan penyelesaiannya. Pembelajaran pada siklus I terdiri dari 2 kali pertemuan.

Perencanaan Pembelajaan Siklus I, pertama guru menyiapkan seluruh perangkat pembelajaran diantaranya yaitu Silabus, RPP, soal tes siklus, lembar observasi , dan jurnal sebagai pedoman dalam kegiatan pembelajaran.

Tindakan Pembelajaran siklus I, Pembelajaran pada siklus I dilaksanakan sebanyak dua kali pertemuan pertama untuk penyajian materi dan tes siklus. Pertemuan pertama melaksanakan pembelajaran pertama-tama peneliti memperkenalkan diri dan memberitahukan bahwa akan diadakan penelitian di kelas VII B, dan peneliti juga menginformasikan bahwa yang menjadi guru untuk pembelajaran matematika dengan materi Himpunan. Selanjutnya pembelajaran dimulai dengan membaca do'a bersama-sama kemudian guru mengecek kehadiran siswa. Guru menginformasikan bahwa materi yang akan dibahas adalah materi Himpunan, karena model pembelajaran yang digunakan adalah model pembelajaran kooperatif, guru pun membagi siswa ke dalam beberapa kelompok. Kelompok yang terbentuk ada 6 kelompok yang beranggotakan 5 orang siswa. 
Sebelum kegiatan pembelajaran dimulai guru terlebih dahulu memberikan informasi tentang pengertian Himpunan.

Guru juga memberi motivasi kepada siswa dengan menjelaskan manfaat materi yang akan diajarkan dalam kehidupan sehari-hari hal tersebut diharapkan agar siswa tertarik untuk menyimak materi yang disampaikan oleh guru. Selanjutnya siswa diharuskan menyimak apa yang akan disampaikan oleh guru yang akan menjelaskan dan memberikan arahan-arahan materi yang akan dibahas, selanjutnya siswa dihadapkan untuk merangkum apa yang telah guru sampaikan, lalu ketua kelompok dari masing-masing kelompok dipanggil untuk menyampaikan materi kepada masing-masing anggota kelompoknya untuk menuliskan satu pertanyaan yang menyangkut materi yang sudah dijelaskan tadi.

Guru memberikan waktu kepada siswa untuk membuat satu pertanyaan dalam waktu 5 menit. Dan mengarahkan siswa berdiskusi dalam membuat soal yang sesuai dengan apa yang telah guru sampaikan. Setelah siswa selesai membuat soal selanjutnya guru mengarahkan untuk siswa membuat gulungan kertas menyerupai bola salju yang terbuat dari kertas-kertas pertanyaan yang telah dibuatt siswa. Selanjutnya siswa diminta untuk melemparkan soal tersebut pada siswa lain, setelah siswa mendapat satu soal satu pertanyaan maka saatnya siswa untuk menjawab pertanyaan tersebut.

Guru berkeliling dari satu kelompok ke kelompok lain untuk mengamati aktivitas siswa, dan membantu siswa yang mengalami kesulitan dalam menyelesaikan soal sambil menilai hasil kerja siswa dengan kelompoknya. Kepada siswa yang berhasil menjawab pertanyaan dari temannya dan menjelaskan kepada teman-temannya yang lain. Guru pun memberikan penghargaan berupa pujian kepada siswa dan memberikan nilai tambahan untuk siswa tersebut. Untuk lebih melatih pemahaman siswa, guru memberikan soal secara individu sebagai bentuk evaluasi. Kemudian lembar kerja yang telah dikerjakan dengan waktu yang ditentukan, dikumpulkan untuk dinilai oleh peneliti, dan sebagai penutup pembelajaran pertama peneliti membimbing siswa untuk menyimpulkan materi yang telah dipelajari. Sebagai tindak lanjut pembelajaran guru memberikan PR.

Pertemuan kedua dilaksanakan pelaksanaan tes siklus I. Pertemuan kedua ini diawali dengan membaca do'a ,mengabsen siswa dan mengkondisikan kelas kemudian guru menginformasikan kembali bahwa hari ini akan dilaksanakan tes siklus I. Sebelum memulai tes siklus guru memberikan apersepsi untuk mengingatkan kembali tentang materi yang disampaikan sebelumnya. Setelah itu guru meminta siswa untuk duduk secara individu, setelah keadaanya kondusif maka siswa diberikan soal tes siklus dan tidak saling mencontek. Setelah siswa selesai menyelesaikan soal tes siklus, siswa diminta mengumpulkan lembar jawaban tes siklus,dan guru memberitahukan materi yang akan dibahas di siklus II. Sebelum pembelajaran berakhir siswa diberikan jurnal untuk diisi oleh siswa agar guru mengetahui pedapat dan sikap siswa terhadap pembelajaran dengan menggunakan model pembeajaran kooperatif tipe Snowball throwing.

Repleksi Tindakan, dilakukan identifikasi dan analisis terhadap tindakan pembelajaran siklus I,maka dilakukan refleksi sebagai bahan pertimbangan untuk perbaikan pembelajaran selanjutnya. Di bawah ini adalah tabel refleksi tindakan pada pembelajaran siklus I.

Pelaksanaan Pembelajaran Siklus II, Pelaksanaan pembelajaran yang dilakukan pada siklus II, disesuaikan dengan RPP. Pokok bahasan pada kegiatan 
pembelajaran di siklus II adalah tentang memahami himpunan bagian. Pembelajaran pada siklus II terdiri dari 2 kali pertemuan. Berikut rincian pertemuan setiap siklusnya.

Tabel 1. Refleksi Pembelajaran Siklus I

\begin{tabular}{|c|c|}
\hline Permasalahan & Saran perbaikan \\
\hline $\begin{array}{l}\checkmark \text { Pada saat diskusi kelompok, siswa } \\
\text { masih ada yang tidak ikut } \\
\text { bekerjasama dan berdiskusi dalam } \\
\text { menyelesaikan soal-soal. }\end{array}$ & $\begin{array}{l}\checkmark \text { Guru harus lebih memperhatikan } \\
\text { siswa yang tidak ikut berdiskusi dan } \\
\text { harus menegurnya. }\end{array}$ \\
\hline $\begin{array}{l}\checkmark \text { Siswa masih ada yang mengobrol } \\
\text { ketika guru menjelaskan materi }\end{array}$ & $\begin{array}{l}\checkmark \text { Guru harus lebih tegas pada siswa } \\
\text { yang mengobrol agar siswa yang lain } \\
\text { tidak terganggu. }\end{array}$ \\
\hline $\begin{array}{l}\checkmark \text { Guru masih sulit dalam mengelola } \\
\text { kelas }\end{array}$ & $\begin{array}{l}\checkmark \text { Guru harus bisa mengelola kelas } \\
\text { dengan baik }\end{array}$ \\
\hline $\begin{array}{l}\checkmark \text { Banyak siswa yang malas untuk } \\
\text { mengerjakan tugas }\end{array}$ & $\begin{array}{l}\checkmark \text { Guru harus memberikan teguran } \\
\text { kepada siswa yang malas } \\
\text { mengerjakan soal-soal }\end{array}$ \\
\hline $\begin{array}{l}\checkmark \text { Pemahaman siswa terhadap soal- } \\
\text { soal masih kurang }\end{array}$ & $\begin{array}{l}\checkmark \text { Guru harus lebih membimbing siswa } \\
\text { agar lebih paham terhadap materi } \\
\text { yang diberikan }\end{array}$ \\
\hline
\end{tabular}

Perencanaan Pembelajaran Siklus II, sama halnya dengan siklus I,menyiapkan perangkat pembelajaran diantaranya yaitu silabus, RPP, tes siklus, lembar observasi, dan jurnal siswa. Sesuai dengan refleksi maka diharapkan guru bisa mengelola kelas lagi dengan baik, bersikap tegas dan bisa lebih memperatikan membimbing siswa yang mengalami kesulitan.

Tindakan Pembelajaran Siklus II, Pembelajaran pada siklus II dilaksanakan Pembelajaran siklus II dilaksanakan sebanyak 2 kali pertemuan untuk penyajian materi dan untuk tes siklus II. Tes siklus II. Materi yang disampaikan pada pertemuan pertama adalah membahas tentang menentukan himpunan bagian dan menentukan banyak himpunan bagian. Pertemuan Pertama, Dilaksanakan pada jam pelajaran ke-1 dan ke-2. Tahapan pelaksanaan pembelajaran sama dengan siklus 1. Pertemuan kedua, Dilaksanakan tes siklus II Pada pembelajaran siklus II ini proses pembelajarannya hampir sama dengan siklus I, yang membedakannya siswa sudah mulai kondusif dari sebelumnyan saat pembelajaran berlangsung.

Refleksi Tindakan, Setelah dilakukan identifikasi dan analisis terhadap tindakan pembelajaran siklus II, maka dilakukan refleksi sebagai bahan pertimbangan untuk perbaikan pembelajaran selanjutnya. Di bawah ini adalah tabel refleksi tindakan pada pembelajaran siklus II.

Pelaksanaan Pembelajaran Siklus III, Pelaksanaan pembelajaran yang dilakukan pada siklus III, disesuaikan dengan RPP. Pokok bahasan pada kegiatan pembelajaran di siklus III adalah tentang Melakukan operasi irisan, gabungan, kurang (difference), dan komplemen pada himpunan.

Perencanaan Pembelajaran Siklus III, Terlebih dahulu menyiapkan perangkat pembelajaran diantaranya yaitu silabus, RPP, menyusun tes siklus, lembar observasi, dan jurnal siswa. Berdasarkan refleksi maka Guru harus mengelola kelas dengan baik, memperhatikan dan memberi teguran kepada siswa yang 
mengobrol dan malas mengerjakan soal serta memberi memotivasi siswa agar siswa mau dan berani mengemukakan pendapat dan lebih efektif dalam penggunaan waktu yang disediakan untuk setiap kegiatan pembelajaran.

Tabel 2. Refleksi pembelajaran siklus II

\begin{tabular}{|c|c|}
\hline Permasalahan & Saran Perbaikan \\
\hline $\begin{array}{llll} & \text { Peneliti masih sulit dalam } \\
\text { mengelola kelas } & & \end{array}$ & $\begin{array}{l}\checkmark \text { Guru harus mengelola kelas dengan } \\
\text { baik }\end{array}$ \\
\hline $\begin{array}{l}\checkmark \text { Pada saat diskusi siswa ada } \\
\text { beberapa yang mengobrol }\end{array}$ & $\begin{array}{l}\checkmark \text { Guru harus lebih memperhatikan dan } \\
\text { memberi teguran kepada siswa yang } \\
\text { mengobrol }\end{array}$ \\
\hline $\begin{array}{l}\checkmark \text { Ada } 2 \text { orang siswa yang malas } \\
\text { mengerjakan soal }\end{array}$ & $\begin{array}{l}\checkmark \text { 3.Guru harus lebih tegas dan memberi } \\
\text { teguran kepada siswa yang malas } \\
\text { mengerjakan soal }\end{array}$ \\
\hline $\begin{array}{l}\checkmark \text { Beberapa siswa belum berani } \\
\text { mengemukakan pendapatnya }\end{array}$ & $\begin{array}{l}\checkmark \text { 4. Guru harus memotivasi siswa agar } \\
\text { siswa mau dan berani mengemukakan } \\
\text { pendapat. }\end{array}$ \\
\hline $\begin{array}{l}\checkmark \text { Waktu yang disediakan dirasa } \\
\text { belum cukup untuk setiap } \\
\text { kegiatan pembelajaran. }\end{array}$ & $\begin{array}{l}5 . \quad \text { Harus lebih efektif dalam } \\
\text { penggunaan waktu yang disediakan } \\
\text { untuk setiap kegiatan pembelajaran. }\end{array}$ \\
\hline
\end{tabular}

Tindakan Pembelajaran Siklus III, Tindakan pembelajaran yang dilakukan pada siklus III, disesuaikan dengan RPP. Pokok bahasan pada tentang Melakukan operasi irisan, gabungan, kurang (difference), dan komplemen pada himpunan. Pertemuan Pertama, Tahapan pelaksanaan pembelajaran sama dengan siklus 2. Pertemuan kedua, Dilaksanakan tes siklus III Pada pembelajaran siklus III ini proses pembelajarannya hampir sama dengan siklus II, yang membedakannya siswa sudah mulai kondusif dari sebelumnyan saat pembelajaran berlangsung.

Refleksi Tindakan, Setelah dilakukan identifikasi dan analisis terhadap tindakan pembelajaran siklus III,maka dilakukan refleksi sebagai bahan pertimbangan untuk perbaikan pembelajaran selanjutnya. Permasalahan yang masih ada pada saat pembelajaran di pertemuan terakhir ini, ada 3 orang siswa yang mengobrol saat pembelajaran berlangsung, dan ada 1 orang siswa yang malas untuk mengerjakan soal. Dari permasalahan tersebut di dapat saran perbaikan diantaranya, guru harus lebih memperhatikan dan memberi teguran kepada siswa yang mengobrol, dan guru harus lebih tegas pada siswa yang malas tersebut.

Berdasarkan pembelajaran pada siklus I, II dan III. Peneliti melakukan analisis untuk memperbaiki pembelajaran pada tindakan selanjutnya. Analisis dilakukan berdasarkan hasil observasi, jurnal dan tes siklus I, II, dan III. Berdasarkan pembelajaran siklus I, pembelajaran dengan model pembelajaran kooperatif tipe Snowball throwing masih belum berjalan dengan baik, hal ini dilihat dari pemahaman siswa masih kurang saat menjawab soal-soal tes siklus I, hal ini memberikan pengaruh terhadap nilai ketuntasan yang masih kebanyakan siswa nilainya kurang dari KKM. Dilihat dari lembar observasi guru, masih kurang dalam pengelolaan waktu dan suasana kelas belum kondusif karena siswa yang belum terbiasa belajar secara berkelompok apalagi sebelumnya memang siswa belum pernah belajar secara berkelompok. Siswa nasih terlihat kaku saat proses 
pembelajaran dengan model pembelajaran kooperatif tipe snowball throwing pada siklus I ini.

Pada siklus II pembelajaran dengan menggunakan model pembelajaran kooperatif tipe snowball throwing sudah mulai mendapat respon yang baik dari sebagian siswa. Pemahaman siswa untuk menjawab soal-soal pun sudah agak naik, hal ini dilihat dari hasil kerja dan tugas yang diberikan guru kepada siswa. Suasana sudah mulai berjalan kondusif meski masih ada sebagian siswa yang yang mengbrol dan cuek terhadap pembelajaran matematika. Guru pun sudah mulai bisa mengatur waktu agar waktu yang disediakan efektif.

Pada siklus III pembelajaran dengan menggunakan model pembelajaran kooperatif tipe snowball throwing sudah berjalan dengan cukup baik, hal ini dilihat dari respon siswa, sikap siswa terhadap guru, pemahaman siswa, dan waktu yang lebih efektif. Siswa yang tadinya tidak paham jadi lebih berani untuk bertanya, siswa memberikan respon yang baik terhadap pembelajaran berdiskusi. Pada siklus terakhir ini sudah dapat disimpulkan bahwa pembelajaran dengan menggunankan model pembelajaran kooperatif tipe snowball throwing dapat meningkatkan aktivitas belajar dan pmahaman siswa.

Hasil analisis tingkat penguasaan terhadap materi untuk setiap siklusnya, diperoleh tingkat penguasaan tertinggi, terendah, rata-rata dan DSK yang disajikan dalam Gambar 1.

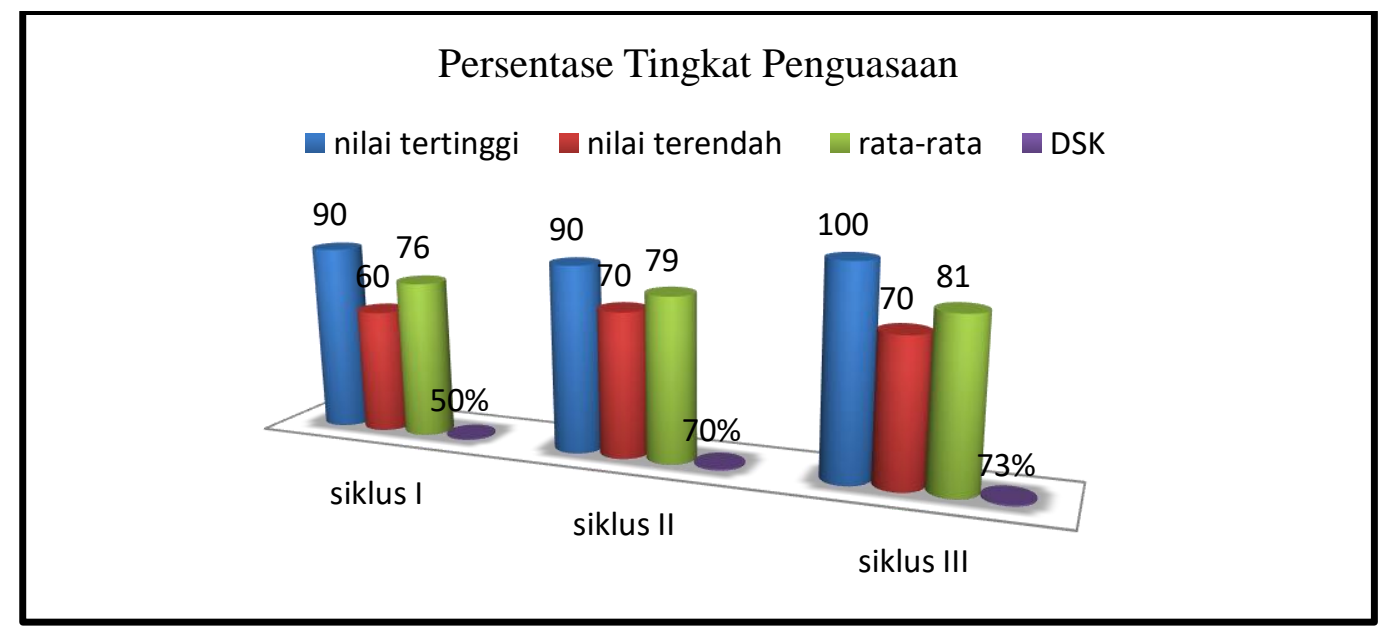

Gambar 1. Tingkat Penguasaan Pemahaman Matematis Siswa Tiap Siklus

Berdasarkan Gambar 1, nilai tertinggi,nilai terendah, rata-rata dan DSK setiap siklusnya mengalami peningkatan. Dengan demikian menunjukan hal positif terhadap penguasaan pemahaman matematis karena adanya peningkatan pada setiap siklusnya.

Hasil analisis tingkat ketuntasan belajar pada setiap siklus, diperoleh persentase ketuntasan belajar yang disajikan pada Tabel 3. Berdasarkan Tabel 3 terlihat ketuntasan pada setiap siklus mengalami peningkatan pada ketuntasan belajar dan mengalami penurunan pada ketidak tuntasan belajar siswa. Hal ini dibuktikan dengan ketercapaian ketuntasan belajar siswa terhadap materi yang telah diberikan kepada siswa semakin dipahami siswa setiap siklusnya. 
Tabel 3. Persentase ketuntasan Belajar Setiap Siklus

\begin{tabular}{llll}
\hline \multicolumn{2}{c}{ Ketuntasan Belajar } & Jumlah Siswa & Persentase \\
\hline Siklus I & Tuntas & 15 & $50 \%$ \\
& Tidak Tuntas & 15 & $50 \%$ \\
Siklus II & Tuntas & 21 & $70 \%$ \\
& Tidak Tuntas & 9 & $30 \%$ \\
\multirow{3}{*}{ Siklus III } & Tuntas & 22 & $73 \%$ \\
& Tidak Tuntas & 8 & $27 \%$ \\
\hline
\end{tabular}

Untuk mengetahui tingkat pemahaman siswa siklus I, II, dan III.Dapat dilihat dari penguasaan pemahaman matematis siswa berdasarkan tes siklus I, II, dan III. Untuk mengetahui peningkatan tingkat pemahaman siswa secara jelas, berikut hasil peningkatan pemahaman siswa siklus I, II, dan III, pada Gambar 2.

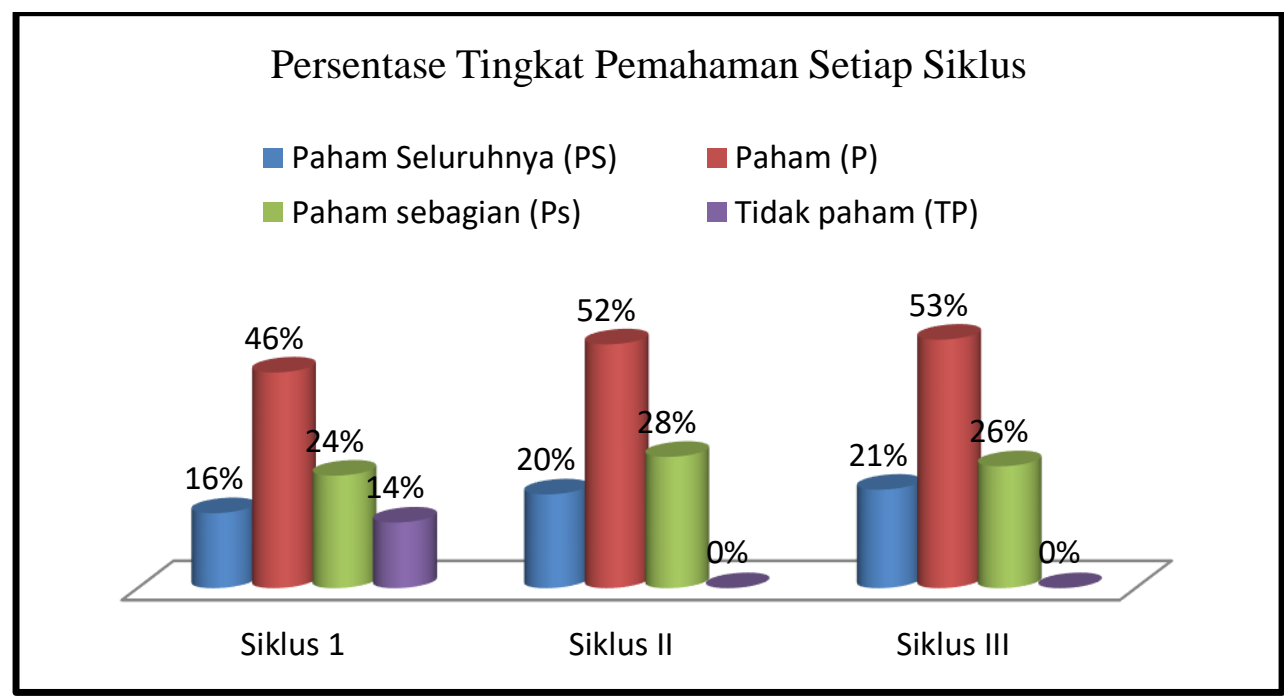

Gambar 2. Presentase tingkat pemahaman siswa setiap siklus

Hasil analisis jurnal harian siswa setiap siklus seagai berikut.

Tabel 4. Persentase sikap siswa berdasarkan jurnal harian setiap siklus

\begin{tabular}{llll}
\hline Pendapat Siswa & Siklus I & Siklus II & Siklus III \\
\hline Positif & $67 \%$ & $77 \%$ & $90 \%$ \\
Negatif & $33 \%$ & $23 \%$ & $10 \%$ \\
Jumlah & $100 \%$ & $100 \%$ & $100 \%$ \\
\hline
\end{tabular}

Pada Tabel 4 terlihat ada peningkatan respon positif siswa dari siklus sebelumnya, berdasarkan hasil persentase siklus III siswa memberikan respon positif sebesar $90 \%$. Hal ini menunjukan bahwa pembelajaran matematika dengan menggunakan model pembelajaran kooperatif tipe snowball throwing, pada umumnya siswa merespon positif.

Hasil analisis aktivitas guru dan siswa setelah melakukan observasi dari siklus I sampai siklus III, maka di dapat hasil analisis level aktivitas guru dan siswa pada setiap siklus. 
Tabel 5. Level aktivitas guru dan siswa pada setiap siklus

\begin{tabular}{clll}
\hline Siklus & Jumlah & Rata-rata & Kategori \\
\hline I & 44 & 2,8 & Baik \\
II & 46 & 2,9 & Baik \\
III & 50 & 3,1 & Baik \\
\hline
\end{tabular}

Berdasarkan data yang di dapat dari observer yang di lakukan oleh guru pada setiap pembelajaran mengalami peningkatan. Hal ini di tunjukan oleh tabel 5 . peningkatan yang ada tidak terlalu signifikan namun hal ini sudah dirasa cukup oleh guru karena dengan adanya peningkatan meski sedikit, ini menunjukan bahwa aktivitas guru dan siswa sangat baik dan dengan adanya peningkatan aktivitas guru dan siswa ini membuat siswa lebih aktif dan berani berpendapat saat pembelajaran berlangsung dibanding dengan sebelum pembelajaran kooperatif dilakukan. Dengan demikian penggunaan model pembelajaran snowball throwing dapat meningkatkan aktivitas guru dan siswa.

Berdasarkan hasil analisis data, maka Pembelajaran matematika dengan menggunakan model pembelajaran snowball throwing dapat meningkatkan pemahaman matematis siswa. Ini di buktikan dengan sebagian besar siswa bisa hafal dengan notasi dan simbol matematika tanpa berpacu pada catatan mereka ini menunjukan bahwa siswa hafal di luar kepala.

Pemahaman matematis didefinisikan sebagai kemampuan yang mengaitkan notasi dan simbol matematika yang relevan dengan ide-ide matematika dan mengkombinasikannya ke dalam rangkaian penalaran logis. Pembelajaran matematika dengan model pembelajaran kooperatif dapat meningkatkan pemahaman siswa, Hal ini bisa dilihat dari hasil DSK yang setiap siklusnya mengalami peningkatan, di siklus I nilai ketuntasan siswa sebesar 50\%, Pada siklus I memang siswa masih kurang dalam pemahaman matematisnya, ini di buktikan dari hasil tes siklus I yang masih kurang.

Pada siklus II disini mulai ada penaikan pemahaman siswa dan di siklus terakhir pin siswa mengalami peningkatan pemahaman. Hal ini berdasarkan nilai ketuntasan siswa sebesar $70 \%$ dan pada siklus III nilai ktuntasan siswa menjadi $73 \%$, hal ini menunjukan bahwa pada setiap siklusnya penaikan ketuntasan siswa juga naik berdasarkan hasil dari tes formatif setiap siklusnya. Ini menunjukan bahwa pemahaman siswa juga ikut naik. Nilai tingkat pemahaman tertinggi mencapai nilai sempurna dan untuk nilai pemahaman terendah sudah semakin baik untuk tiap siklusnya. Hal ini menunjukan adanya peningkatan dan hasil yang baik pada setiap tes siklusnya dengan penggunaan model pembelajaran kooperatif tipe snowball throwing pada pokok bahasan himpunan.

Pembelajaran matematika dengan model pembelajaran snowball throwing sangat disenangi siswa, ini ditunjukan dengan sikap siswa yang merespon positif dan jika pembelajaran di mulai siswa selalu ingin bekerja kelompok. Siswa sangat antusias terhadap pembelajaran dengan menggunakan snowball throwing. Suasana pembelajaran siswa jadi menyenangkan karena siswa sangat menyukai sesi pelemparan bola salju (lembar soal). Definisi model pembelajaran snowball throwing sesuai dengan apa yang di kemukakan oleh Kisworo (2008) bahwa model pembelajaran snowball throwing adalah suatu metode pembelajaran yang diawali dengan pembentukan kelompok yang diwakili ketua kelompok untuk mendapat tugas dari guru kemudian masing-masing siswa membuat pertanyaan 
yang dibentuk seperti bola (kertas pertanyaan) lalu dilempar ke siswa lain yang masing-masing siswa menjawab pertanyaan dari bola yang diperoleh.

Setelah melihat peningkatan tingkat pemahaman siswa, peneliti juga meliahat bagaimana suasana keaktifan siswa saat pembelajaran berlangsung dengan penggunaan model pembelajaran snowball throwing. Hal ini dapat dilihat dari hasil observasi aktivitas siswa yang pada siklus I masih banyak siswa yang belum terbiasa dengan pembelajaran kooperatif, sehingga keaktifan siswa masih kurang terhadap pembelajaran matematika dengan menggunakan model pembelajaran kooperatif. Selanjutnya pada hasil observasi di siklus II siswa sudah mulai berani dan sudah tidak kaku dan cuek terhadap pembelajaran matematika dengan menggunakan kooperatif ini. Sebagian siswa sudah berani bertanya. Keaktifan siswa dan guru selalu meningkat pada setap siklusnya, Meskipun tidak signifikan. Pada siklus I nilai rata-rata hasil observasi yaitu sebesar 2,8 yang di kategorikan baik. Peneliti berusaha untuk meningkatkan hasil observasi dan membuat belajar siswa lebih menyenangkan.

Suasana saat pembelajaran pada siklus I, memang belum kondusif ini dikarenakan siswa belum terbiasa, apalagi sebelumnya guru matematika hanya menggunakan metode pembelajaran yang bersifat konvensional. Tanpa penggunakan model atau metode pada pembelajaran matematika siswa akan merasa bosan dan jenuh dengan pembelajaran matematika. Ini mempengaruhi keaktifan siswa dan juga hasil belajar siswa. pada siklus II nilai rata-ratanya mulai naik menjadi 2,9 yang di kategorikan baik. Pada siklus ini Sudah terlihat siswa mulai kondusif tidak seperti sebelumnya dan pada siklus III siswa sudah terlihat lebih nyaman dan belajarnya lebih menyenangkan dari siklus sebelumnya dengan perolehan nilai rata-rata observasinya sebesar 3,1 yang di kategorikan baik. Ini menunjukan siswa lebih kondusif terhadap pembelajaran matematika dengan menggunakan model pembelajaran kooperatif.

Siklus ke III sekaligus siklus terakhir, semakin terlihat adanya peningkatan keaktifan siswa hal ini dibuktikan baik dari data hasil observasi ataupun dari perilaku siswa, perilaku siswa disini seperti siswa lebih berani menyampaikan pendapatnya, siswa berani untuk bertanya, kritis dan tentunya lebih aktif. Dengan demikian dapat disimpulkan bahwa penggunaan model pembelajaran kooperatif tipe snowball throwing dapat meningkatkan keaktifan siswa dan suasana saat pembelajaran berlangsung kondusif.

Berdasarkan hasil analisis data jurnal, dimana jurnal digunakan pada setiap akhir proses pembelajaran pada setiap pertemuannya. Jurnal digunakan untuk mengetahui sikap siswa terhadap pembelajaran kooperatif dan untuk menjadi bahan refleksi untuk pertemuan selanjutnya. Hasil analisis jurnal membuktikan bahwa pada setiap siklusnya mengalami peningkatan komentar positif dan pengurangan komentar negatif pada setiap siklusnya. Pada siklus I, berdasarkan jurnal siswa inilah hasil komentar positif siswa yaitu sebesar $67 \%$ dan pada siklus II yaitu sebesar $77 \%$ dan siklus III sebesar $90 \%$, dari data tersebut menunjukan adanya peningkatan pada setiap siklusnya.

Sejalan dengan peneltian Sadiah, Komala \& Sugiarni (2019) kemampuan pemahaman konsep matematika meningkat siswa di kelas VII SMP Al-Azhary Cianjur. Penelitian lain juga menunjukan bahwa Novitasari \& Pujiastuti (2020) pembelajaran snowball throwing dapat meningkatkan keaktifan elajar siswa SMP. 
Pembelajaran snowball throwing alternatif dalam meningkatkan pemahaman dan keaktifan siswa dalam elaar matematika.

\section{KESIMPULAN}

Berdasarkan hasil penelitian dan pembahasan yang telah peneliti uraikan, maka dapat disimpulkan bahwa implementasi model pembelajaran snowball throwing dapat meningkatkan pemahaman matematis siswa pada pembelajaran matematika. Terlihat dari rata-rata pemahaman matematis siswa meningkat dari 75(siklus I), menjadi 9 (siklus II), dan 82 (siklus III). Peningkatan juga terjadi pada pencapaian daya serap dan ketuntasan belajar. Pencapaian daya serap meningkat dari $50 \%$ menjadi $70 \%$ dan $73 \%$. Adapun ketuntasan belajar mengalami peningkatan dari $50 \%$ enadi 0 dan $73 \%$. Penggunaan model pembelajaran snowball throwing dapat meningkatkan aktivitas siswa saat belajar diantaranya, siswa jadi lebih aktif,siswa jadi lebih berani mengemukakan pendapatnya, kritis dan lebih kompak saat kerja sama kelompok. Suasana pembelajaran menjadi menyenangkan bagi sisw. Sikap siswa merespon positif.

\section{REFERENSI}

Abdurrahman, M., \& Bintoro, T. (2000). Memahami dan Menangani Siswa dengan Problema dalam Belajar: Panduan Guru. Jakarta: Direktorat Jendral Pendidikan Dasan dan Menengah, Departemen Pendidikan Nasional.

DEPDIKNAS. (2005). Matematika. Jakarta Dirjen Dikti Departemen Pendidikan Nasional.

Fajriah, N., \& Sari, D. (2016). Meningkatkan Pemahaman Konsep Matematis Siswa pada Materi SPLDV melalui Model Pembelajaran Kooperatif Tipe Think-Pair-Share di Kelas VIII SMP. EDU-MAT: Jurnal Pendidikan Matematika, 4(1), 68-75.

Gross, J.J., \& Thompson, R.A. (2007). Emotion regulation: Conceptual foundations. In Handbook of emotion regulation. New York: Guilford Press.

Hutagalung, R. (2017). Peningkatan kemampuan pemahaman konsep matematis siswa melalui pembelajaran guided discovery berbasis budaya toba di smp negeri 1tukka. MES: Journal of Mathematics Education and Science, 2(2), 7077.

Kisworo. (2008). Cooperative Learning. Yogyakarta: Pustaka Pelajar

Mawaddah, S., \& Maryanti, R. (2016). Kemampuan Pemahaman Konsep Matematis Siswa SMP dalam Pembelajaran Menggunakan Model Penemuan Terbimbing (Discovery Learning). EDU-MAT: Jurnal Pendidikan Matematika, 4(1), 76-85.

NCTM. (1989). Curriculum and Evaluation Standards for School Mathematics. Reston, VA: NCTM

Ningrum, E. K., Purnami, A. S., \& Widodo, S. A. (2017). Eksperimentasi Team Accelerated Instruction terhadap Kemampuan Pemecahan Masalah Matematika Ditinjau dari Kemampuan Awal Siswa. JNPM (Jurnal Nasional Pendidikan Matematika), 1(2), 218-227. 
Novitasari, J., \& Pujiastuti, H. (2020). Penerapan Model Pembelajaran Snowball Throwing Untuk Meningkatkan Keaktifan Matematis Materi Lingkaran Pada Siswa SMP. Barekeng: Jurnal Ilmu Matematika dan Terapan, 14(3), 357-364.

Nurdiawan, R., Maryam, M. S., Lutfia, L., Trisatria, T., Hermawan, W., \& Hidayat, W. (2019). Analisis Kemampuan Pemahaman Matematis terhadap Prokrastinasi Akademik Siswa dalam Matematika. Journal On Education, 1(3), 65-74.

Ruseffendi, E.T. (1991). Pengantar kepada Membantu Guru Mengembangkan Kompetensinya dalam Pengajaran Matematika untuk Meningkatkan CBSA. Bandung: Tarsito

Rusmana, I. M., \& Isnaningrum, I. (2015). Efektifitas Penggunaan Media ICT dalam Peningkatan Pemahaman Konsep Matematika. Formatif: Jurnal Ilmiah Pendidikan MIPA, 2(3), 198-205.

Sadiah, A. S., Komala, E., \& Sugiarni, R. (2019). Peningkatan Kemampuan Pemahaman Konsep Matematika Siswa Melalui Model Pembelajaran Probing Prompting. Pi: Mathematics Education Journal, 2(2), 69-73.

Septian, A., \& Ramadhanty, C. L. (2020). Peningkatan pemahaman konsep matematika siswa SMP melalui model pembelajaran kooperatif tipe jigsaw. Wacana Akademika: Majalah Ilmiah Kependidikan, 4(1), 56-63

Suherman, E., dkk. (2003). Strategi Pembelajaran Matematika Kontemporer. Bandung: UPI.

Sumarmo, U. (2010). Berpikir dan Disposisi Matematik: Apa, Mengapa, dan Bagaimana Dikembangkan pada Peserta Didik. Artikel pada FPMIPA UPI Bandung.

Suprijono, A. (2010). Cooperative learning: Teori \& Aplikasinya. Yogyakarta: Pustaka Pelajar.

Syafrianto, S., Kusumah, Y. S., \& Juandi, D. (2016). Peningkatan Kemampuan Pemahaman Matematis dan Kebiasaan Berpikir (Habits Of Mind) Siswa SMP melalui Modelpembelajaran Kooperatif Tipe Make A Match. Sigma Didaktika: Jurnal Pendidikan Matematika, 4(2), 170-180.

Widodo, S. A., Ayuningtyas, A. D., \& Sumarti, S. (2019). Peningkatan Prestasi Belajar Dengan Menggunakan Pembelajaran Kolaboratif Tipe Jigsaw. PRISMA, 8(2), 111-123. 